\title{
FAILURE OF REMANUFACTURED GEARS
}

\author{
Béla CSORBA ${ }^{1}$, Ferenc VÉGVÁRI ${ }^{2}$ \\ John von Neumann University, GAMF Faculty of Engineering and Computer Science, Kecskemét, Hungary \\ ${ }^{1}$ Department of Natural and Technical Sciences, csorba.bela@gamf.uni-neumann.hu, \\ ${ }^{2}$ Department of Materials Technology, vegvari.ferenc@gamf.kefo.hu
}

\begin{abstract}
Gears are torque and motion transmision elements required for gearboxes. Adequate consideration must be given to the material selection and heat treatment of these gears. Inappropriate material selection or heat treatment will lead to premature failure of the manufactured gears or early refurbishment. In our publication, we present a number of practical failures that can be traced back to wrong material selection or heat treatment operation.
\end{abstract}

Keywords: gears failure, material selection for gears, heat treatment for gears.

\section{Damage to gears}

In engineering, it is often necessary to design, implement, and repair gears that have been used for years. If manufacturing and repairing do not reflect the necessary expertise, the manufactured engines can go wrong too soon.

\section{Material selecting}

The first step in the manufacturing process is choosing the starting material. When selecting the material, we must take into account the dimensions of the gear to be manufactured, the size of the module, the way how it will be used and how many will be produced. In case of a less-used gear non-alloy steel can be appropriate, while increased bearing demands steel with chromium, manganese alloys. For a gear with heavy dynamic bearing it may be necessary to choose steel with nickel alloy in addition to the previously listed alloys. Breakdowns due to the inappropriate mate-rial selection are presented below.

\subsection{Choice of non-alloy structural steel}

One very serious mistake is if the starting material is selected from non-alloy structural steel marked A50, A60 according to the old, or S355J2 according to the new marking system. This steel does not belong to the heat treatable types of steel. The so produced gear can be good for geometry, but it is inappropriate for real use. Figure 1. shows a structural steel cone gearwheel made for general purposes which went wrong too soon. The teeth, after a short period of use became edgy and worn out.

There might be problems even if we use heat-treatable steel of higher quality when heat treatment is abandoned or improperly performed. In Figure 2, a $132 \mathrm{~kW}$ Flender KENW 320 pump has a failed gear, after only 159 hours operating time. [1] The gear shown in Figure 2. is made of material C60. In order to find bark thickness, Vickers hardness test was carried out perpendicularly to the tooth surface, the results of which are shown in Figure 3. The figure shows

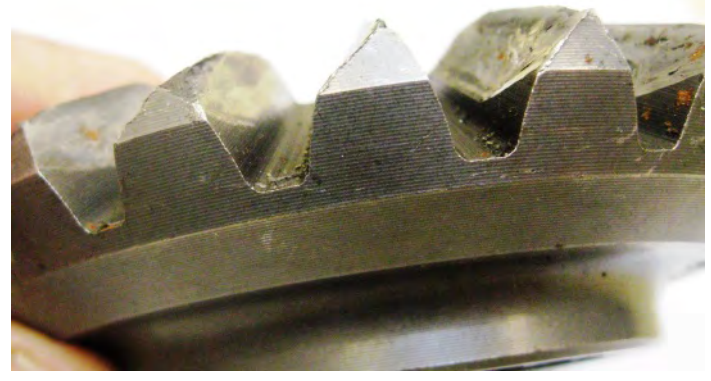

Figure 1. Soon worn gear made of structural steel 


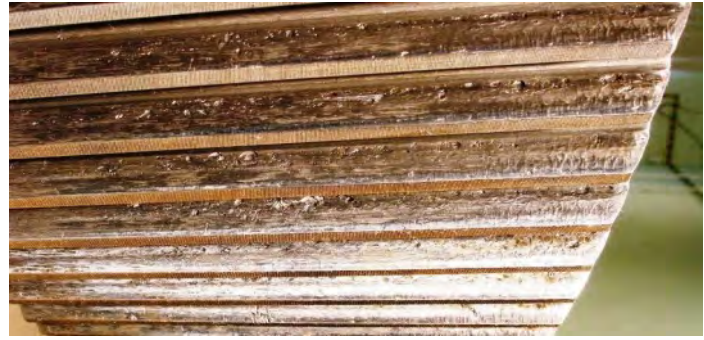

Figure 2. Non-heat-treated gears made of C60 steel after 159 hours of operation

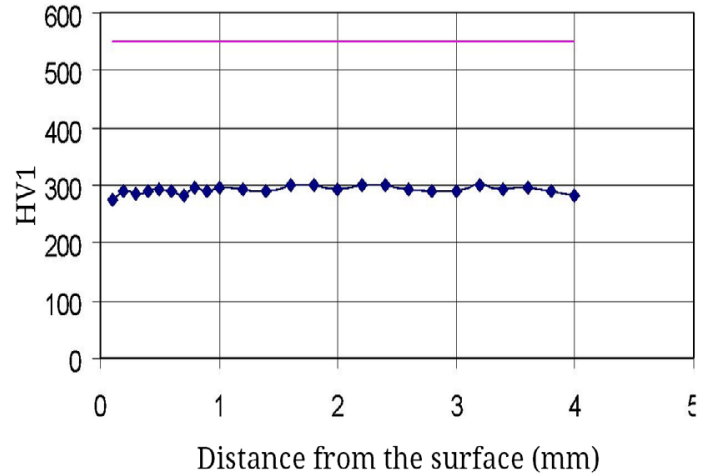

Figure 3. No hardened bark can be seen on the steel gear made of $C 60$

that there was no bark on the surface. The measured 300HV1 hardness could be a normalized, possibly a very tempered structure.

\subsection{Selection of alloyed structural steel}

Gears can also be made of alloyed improvable steel. Figure 4. illustrates how - after 159 hours of operation - gear wheel with slanting teeth of the previously shown engine made of steel $42 \mathrm{CrMo} 4$ goes wrong due to heavy bearing.

There was no bark thickness on the gear wheel. The hardness was $300 \mathrm{HV} 1$ here as well. There is a large pitting on the surface of the teeth resulting from surface fatigue due to high stress (Hertzstress). This is well demonstrated by cracks from fatigue on the cut at the right angle to the surface. (Figure 5.).

\section{Heat treatment}

After the appropriate material selection, the gears manufactured must be heat treated as well. The operation must be carried out with due care and caution.

Figure 6. shows the failure of a trained insertion piece made of $16 \mathrm{MnCr} 5$ material. The part

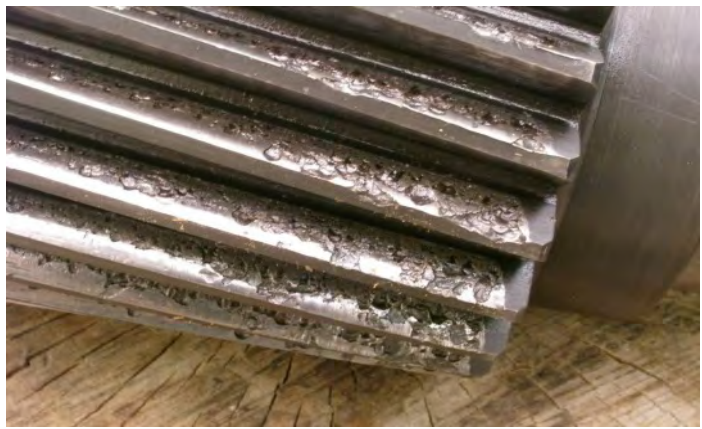

Figure 4. Gear wheel with no heat treatment made of steel 42CrMo4 going wrong after 159 hours of operation

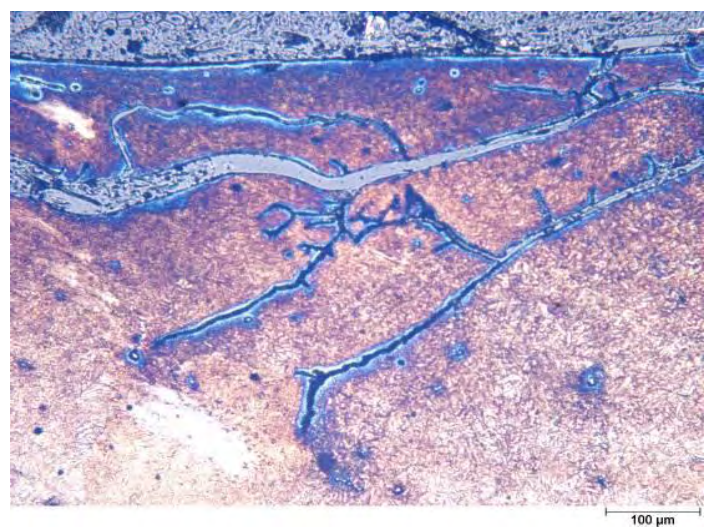

Figure 5. Cracks caused by surface fatigue

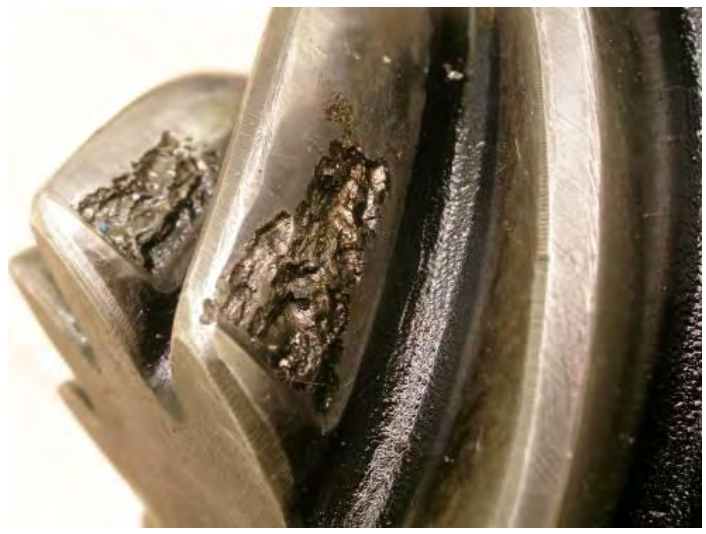

Figure 6. Failure of stainless steel made of $16 \mathrm{MnCr} 5$ scraper within a one-week operation

running continuously did not reach a week without failure. The bark thickness achieved during insertion hardening was determined and measured (Figure 7.), giving a result of $0.85 \mathrm{~mm}$.

The above mentioned planetary carrier was subjected to high surface pressure, and the stress on the surface is likely to exceed the permissible value of Hertz's stress, so it has been largely pitted 


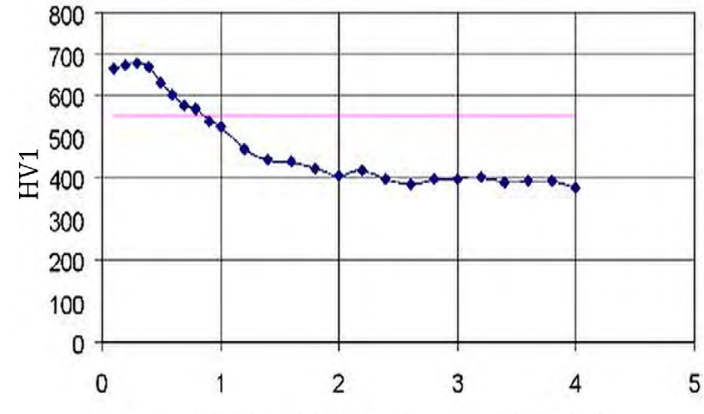

Distance from the surface $(\mathrm{mm})$

Figure 7. Bark thickness of planetary carrier made of $16 \mathrm{MnCr} 5$ steel

due to repeated en-durance. The bark thickness on the gear-wheel is at the lower limit of the bark thickness suggested for the 5 to 6 modules ( 0.8 to $1.2 \mathrm{~mm}$ ). In addition to the increased surface stress, the teeth could not be evenly burdened along their entire length due to inaccurate manufacturing or assembly. The transmission of torque was only subject to $\sim$ half the length of the teeth.

\section{Repairing}

Agricultural machines quite often work in very harsh conditions. Sprockets are ex-posed to weather conditions, precipitation, dust, etc. again and again. In the absence of lubrication, they soon get worn (Figure 8.). In many cases the gears in the protected area also operate in a very dusty environment.

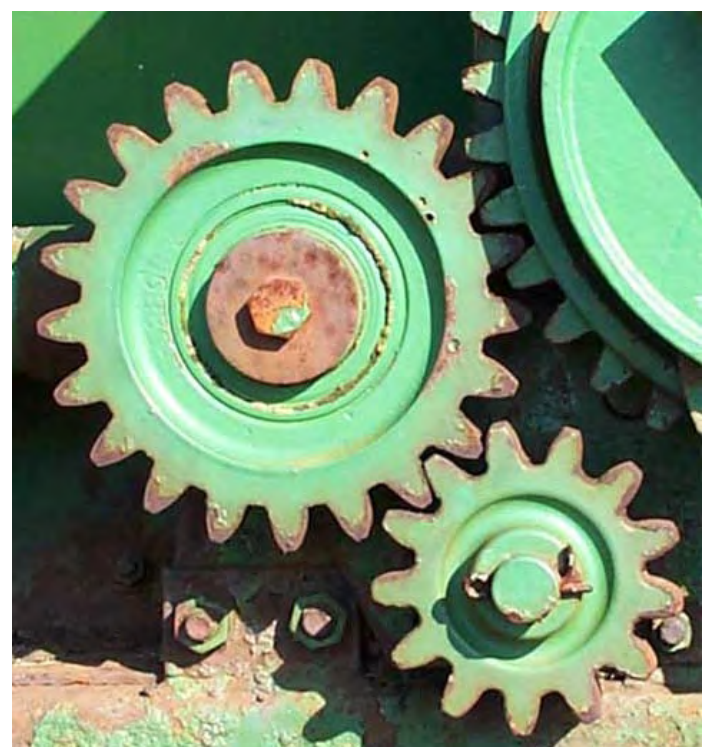

Figure 8. Outbound Gears of Agricultural Machinery [3]
Renewing gears on agricultural ma-chines also lacks occasionally the expertise or responsibility. The ribs of the rib shaft shown in Figure 9. got pointed after a few hours of operation. The particle grinding revealed that the defective ribbing was improved by welding (Figure 10.). The hardness of the welded part is only $220-230 \mathrm{HV} 0.2$.

\section{Conclusions}

a) The material selection of the gears to be produced in small series or to be repaired must be hardened steel

b) In the case of well-chosen material quality, with the heat treatment it is necessary to provide a sufficient thickness of cemented or hardened layer.

c) When repairing toothed gears, the heat input entails expansion.

\section{Acknowledgement}

This research is supported by EFOP-3.6.1-16-201600006 The development and enhancement of the research potential at John von Neumann University project. The Project is supported by the Hungarian Government and co-financed by the European Social Fund.

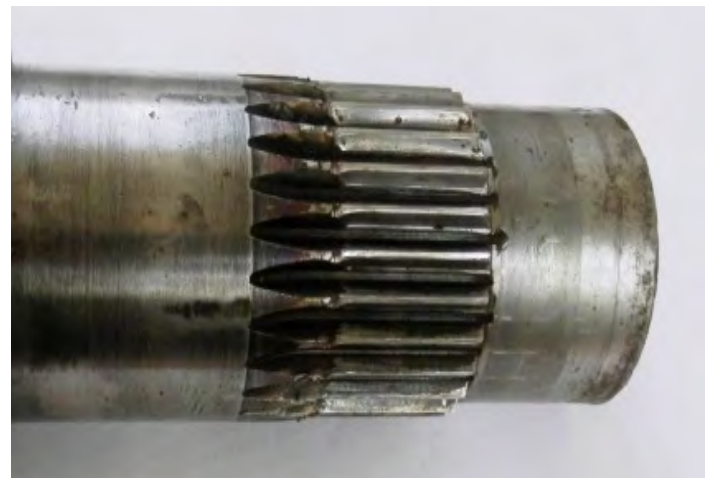

Figure 9. Agricultural machine after repairing its sharpened toothed shaft

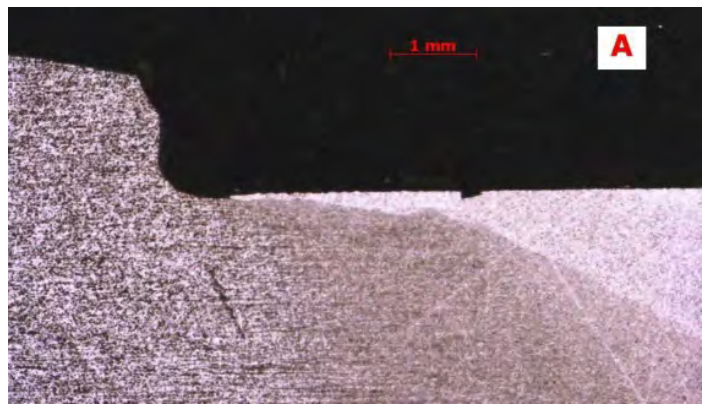

Figure 10. The toothed shaft was repaired by welding 


\section{References}

[1] Bernáth M.; Végvári F: Flender KENW 320 szivattyú hajtómüvének meghibásodása. MECH-TECH Hőkezelő Bt Szakvélemény 2011.

[2] Bernáth M.; Végvári F: Kukorica betakaritó kombájn csőtörö adapter tönkremenetelének vizsgálata, MECH-TECH Hőkezelő Bt Szakvélemény 2014.

[3] https://hu.wikipedia.org/wiki/Fogasker\%C3\%A9k 